\title{
Critical Role of Nitric Oxide During the Apoptosis of Peripheral Blood Leukocytes from Patients with AIDS
}

\author{
M. Djavad Mossalayi, ${ }^{1,2}$ Pierre-André Becherel, ${ }^{1}$ and \\ Patrice Debré ${ }^{1}$ \\ ${ }^{1}$ Molecular Immunohematology Group, Pitié-Salpêtrière Hospital, \\ Paris, France \\ ${ }^{2}$ Laboratory of Immunology and Parasitology, Pharmacy Faculty, \\ University of Bordeaux 2, Bordeaux, France \\ Accepted October 14, 1999.
}

\begin{abstract}
Background: Highly active antiretroviral therapies (HAART) increase the $\mathrm{CD}^{+}$cell count, but complete normalization of this parameter has not been obtained in some patients. As oxidative stress plays an important role during human immunodeficiency virus type 1 (HIV-1)-associated dementia and lymphocyte apoptosis, we asked whether the nitric oxide (NO) pathway plays a role in the in vitro survival of peripheral blood mononuclear cells (PBMC) from HIV $-1^{+}$patients and how it correlates with peripheral $\mathrm{CD} 4^{+}$cell levels.

Materials and Methods: PBMC were isolated from patients with AIDS and assayed for apoptosis and proliferation in the presence of various chemicals, including agonists or antagonists of the NO path-
\end{abstract}

way. Data were then compared with several in vivo parameters from the same patients.

Results: Apoptosis of PBMC in the presence of exogenous NO is significantly higher in patients with low peripheral $\mathrm{CD}^{+}$cell levels than in patients with high $\mathrm{CD}^{+}$cell numbers or seronegative individuals. In addition, endogenous NO inhibition rescues cells from apoptosis in ADS patients with low circulating $\mathrm{CD}^{+}$cell numbers and helps recovery of the $\mathrm{T}$ cell proliferative response. NO-mediated apoptosis does not require CGMP but involves peroxynitrite generation, PARP activation, and $\mathrm{NAD}^{+}$depletion.

Conclusions: Taken together, the data suggest the involvement of NO during the apoptosis and functional impairment of lymphocytes in patients with AIDS.

\section{Introduction}

HIV- 1 infection leads to a progressive depletion of $\mathrm{CD}^{+} \mathrm{T}$ lymphocytes. Several abnormal acquired characteristics of these cells and their microenvironment have been described to explain their anergy and accelerated death $(1,2)$. Oxidative stress plays a critical role during lymphocyte apoptosis in patients with AIDS (1-4). Among oxidants, the role of nitric oxide (NO) in this phenomenon remains to be deter-

Address correspondence and reprint requests to: Dr. $M$. Djavad Mossalayi, Laboratory of Immunology and Parasitology, UFR Pharmacie, Université de Bordeaux 2, 146, Rue Léo Saignat, 33076 Bordeaux Cedex, France. Phone: 3355757 1243; Fax: 3355693 8883; E-mail: djavad.mossalayi@umr5540.u-bordeaux2.fr mined, although many authors have suggested a role for $\mathrm{NO}$ in various neurologic manifestations during AIDS (5-8). NO generation is mediated through the induction of macrophage inducible nitric oxide synthase (iNOS) by various inflammatory mediators and viral particles (reviewed in ref. 9). Cocultures of astrocytes with HIV-1-infected macrophages, but not uninfected cells, induced NO release (10). NO expression was also induced in glial cells by HIV-l gp4l (11).

Highly activated antiretroviral therapies (HAART), a combination of inhibitors of HIV-1 reverse transcriptase and protease, increases the $\mathrm{CD}^{+}$cell count, but complete normalization has not been obtained in some of patients (12). In 
the current study, we first showed that peripheral blood mononuclear cells (PBMC) from patients with peripheral low $\mathrm{CD} 4^{+}$cell counts still present an accelerated apoptosis compared to cells derived from other HAART-treated patients or uninfected donors. As these cells are more sensitive to the proapoptotic effect of oxidative burst than cells from uninfected individuals (3), we asked if they are also more sensitive to NO. We then investigated the role of NO during in vitro apoptosis of leukocytes from AIDS patients undergoing HAART. PBMC were evaluated for their sensitivity to NO inhibitors or chemical NO donor. Correlation between these findings and various in vivo parameters from the same patients were also investigated.

\section{Materials and Methods}

\section{Patients and Controls}

Peripheral blood was obtained from HIV-1-infected patients with AIDS (defined by various parameters according to the Centers for Disease Control, AIDS surveillance case control) with their informed consent. All of these patients had undergone $>7$ months of HAART, with satisfactory results (Table 1). Following cell centrifugation, plasma was separated for the quantification of viral load and levels of tumor necrosis factor- $\alpha$ (TNF- $\alpha$ ) and nitrites. PBMC were isolated using centrifugation on Ficoll-Hypaque gradient. Control PBMC and plasma were obtained from peripheral blood from $\mathrm{HIV}^{-}$healthy volunteers (33-52 years of age).

\section{In Vitro Cultures}

PBMC were incubated in Dulbecco's modified Eagle medium (DMEM) culture medium supplemented with $10 \%$ human pooled antibody sera (Jacques Boy, Paris, France), penicillin/streptomycin, sodium pyruvate, HEPES, and L-glutamine (Gibco-BRL, Cergy Pontoise, France). Cells were also incubated in the presence of $L$ NMMA ( $\mathrm{N}^{G}$ monomethyl-L-arginine, nonspecific NOS inhibitor) or negative control (D-NMMA), L-NIL ( $N$-iminoethyl-L-lysine, a selective inhibitor of NOS-II), SNAP ( $S$-nitroso- $N$-acetyl-D,Lpenicillamine, chemical NO donor), Ly-83,583 (inhibitor of cGMP generation), ODQ (oxadiazole quinoxaline, specific inhibitor of NO-induced soluble guanylyl cyclase), superoxide dismutase (SOD) (all from Alexis, Läufelfingen, Switzerland); nicotinamide and 3-aminobenz- amide (inhibitor of poly-ADP-ribose-polymerase, PARP) or their inactive analogues nicotinic acid and 3-aminobenzoic acid (Sigma-Aldrich, St. Quentin Fallavier, France). The optimal concentrations of these reagents were determined in preliminary analysis. For cell proliferation assay, PBMC $\left(10^{5} / \mathrm{ml}\right)$ were incubated in the presence of plate-bound anti-CD3 (UCHTl clone, a gift from P. C. L. Beverley, IRCF, London, U.K.) and a suboptimal concentration of recombinant IL-2 (25 U/ml; Boehringer-Manheim, Meylan, France).

\section{Quantification of Various Factors}

Plasma TNF- $\alpha$ was determined by specific enzyme-linked immunoabsorbent assay (ELISA; Genzyme, Cambridge, MA). The stable endproduct of NO, nitrites, were detected using a modified Greiss reaction as detailed elsewhere (13). Viral load was presented as plasma HIV-1 RNA copies/ml as determined by reverse transcriptase polymerase chain reaction (RT-PCR; Roche Molecular Systems, Meylan, France).

\section{Assessment of Cell Survival and Apoptosis}

Viable nonapoptotic cells $(>500)$ were counted 4-6 days post-incubation as those not reacting with propidium iodide and annexin-FITC (Sigma-Aldrich). The results were analyzed and compared using the Student's $t$-test for paired data.

\section{Results}

Increased In Vitro Apoptosis of PBMC from Patients with AIDS in the Presence of NO

Sensitivity of PBMC to exogenous NO is assayed by incubating freshly isolated cells $(<6 \mathrm{hr})$ from 17 patients with AIDS (designated by $P$ in Table 1 ) in the presence of $100 \mu \mathrm{M}$ SNAP. Following 4-6 days of incubation, the number of viable (propidium iodide $^{-}$), nonapoptotic (annexine ${ }^{-}$) cells was obtained through direct cell counting. PBMC from 10 healthy seronegative individuals were also incubated under the same culture conditions. Data in Figure 1 indicate that, in medium alone, the percentage of in vitro cell death is greater in cells from patients with AIDS than in controls $(p<0.02)$. Exogenous NO induced significantly higher apoptosis in AIDS cells than in cells from seronegative individuals $(p<0.009)$. However, variable sensitivity to NO was observed within AIDS patients. As shown in Table 2, PBMC from patients with low $\left(<300 / \mathrm{mm}^{3}\right)$ peripheral blood $\mathrm{CD}^{+}$cell counts 
Table 1. Correlation between patient in vivo parameters and plasma TNF- $\alpha$ and nitrite content ${ }^{a}$

\begin{tabular}{|c|c|c|c|c|c|}
\hline Patient & Age & $\mathrm{CD} 4 / \mathrm{mm}^{3 a}$ & Viral load RNA/ml ${ }^{a}$ & $\mathrm{TNF}-\alpha(\mathrm{pg} / \mathrm{ml})^{a}$ & Nitrites $(\mu \mathrm{M})^{a}$ \\
\hline $\mathrm{Pl}^{b}$ & 38 & 185 & $<200$ & 46 & 7.9 \\
\hline P2 & 53 & 487 & 2801 & 32 & 7.9 \\
\hline P3 & 45 & 350 & 33414 & 0 & 9.3 \\
\hline P4 & 44 & 257 & $<200$ & 6 & 7.1 \\
\hline P5 & 41 & 785 & $<200$ & 37 & 4.8 \\
\hline P6 & 39 & 301 & 337 & 10 & 3.1 \\
\hline P7 & 40 & 134 & $<200$ & 0 & 34.8 \\
\hline P8 & 41 & 404 & 447 & 0 & 7.0 \\
\hline P9 & 48 & 235 & 2810 & 19 & 33.7 \\
\hline P10 & 38 & 158 & $<200$ & 0 & 14.6 \\
\hline $\mathrm{P} 12$ & 52 & 291 & $<200$ & 9 & 7.3 \\
\hline P13* & 31 & 400 & 1594 & 27 & NT \\
\hline P20 & 52 & 254 & $<200$ & 389 & 33.8 \\
\hline P21 & 76 & 132 & 12022 & 373 & 18.2 \\
\hline P22 & 41 & 350 & $<200$ & 749 & 1.1 \\
\hline P23 & 38 & 158 & $<200$ & 11 & 6.4 \\
\hline P24 & 52 & 231 & 645 & 862 & 5.5 \\
\hline W11 & 43 & 341 & $<200$ & 9 & 30.2 \\
\hline W14 & 48 & 307 & 2169 & 31 & 14.4 \\
\hline W15 & 59 & 568 & $<200$ & 0 & 19.2 \\
\hline W16* & 55 & 284 & $<200$ & 0 & 7.1 \\
\hline W17 & 52 & NT & $<200$ & 13 & 20.8 \\
\hline W18 & 48 & 113 & 1903 & 0 & $<1.0$ \\
\hline W19* & 31 & 468 & 2553 & 230 & 14.8 \\
\hline W25 & 53 & 395 & 2801 & 35 & 21.7 \\
\hline W26 & 36 & 515 & $<200$ & 25 & $<1.0$ \\
\hline W27 & 52 & 284 & $<200$ & 502 & 11.7 \\
\hline W28 & 39 & 162 & 1017 & 286 & 4.2 \\
\hline W29 & 38 & 343 & 246 & 23 & 42.6 \\
\hline W30* & 45 & 581 & 44129 & 19 & 5.5 \\
\hline W31 & 34 & 244 & 43207 & 802 & $<1.0$ \\
\hline W32 & 46 & 530 & $<200$ & 18 & 4.1 \\
\hline W33 & 37 & 59 & 14031 & 0 & 8.6 \\
\hline W34 & 46 & 193 & $<200$ & 0 & $<1.0$ \\
\hline W35 & 25 & 412 & $<200$ & 206 & 11.5 \\
\hline
\end{tabular}

${ }^{a}$ Patients with AIDS received HAART for $>7$ months. Various parameters were analyzed simultaneously (see Materials and Methods for more details).

${ }^{b}$ Patients undergoing apoptosis analysis are numbered first with $\mathrm{P}$, and those analyzed only for serum factors are numbered W. Females are designated with an asterisk.

(10/17) had a higher in vitro sensitivity to the proapoptotic effect of NO than those with $>300$ $\mathrm{CD}^{+}$cells $/ \mathrm{mm}^{3}$ (7/17). In contrast, sensitivity to NO was not correlated with viral load in the same patients (Table 1).
NO Inhibition Rescues PBMC from Cell Death in Patients with AIDS

The high sensitivity of patient cells to exogenous NO led us to investigate the role of endogenous NO 


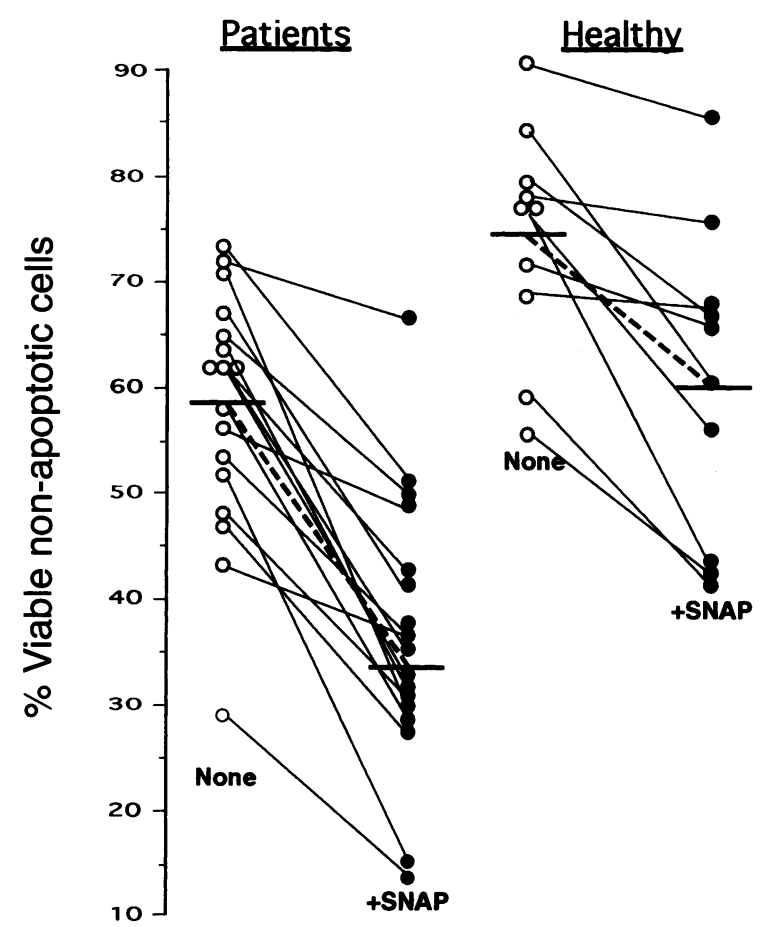

Fig. 1. Effect of NO on PBMC apoptosis. Cells from patients with AIDS or healthy seronegative donors were incubated $\left(10^{6} / \mathrm{ml}\right)$ in medium alone (None) or in the presence of $100 \mu \mathrm{M}$ SNAP. The percentage of surviving (propidium iodide ${ }^{-}$) nonapoptotic (annexine ${ }^{-}$) cells (compared to seeded cells, $100 \%$ ) was obtained. Each circle represents a different donor. Thick bars show means.

during in vitro apoptosis of patients' PBMC. Cells were incubated in culture medium supplemented with an inhibitory analog of L-arginine, L-NMMA $(500 \mu \mathrm{M})$. When normal cells were incubated with L-NMMA (Fig. 2), most of populations showed no sensitivity, whereas some had increased or a slight inhibition of cell death. In contrast, treatment of

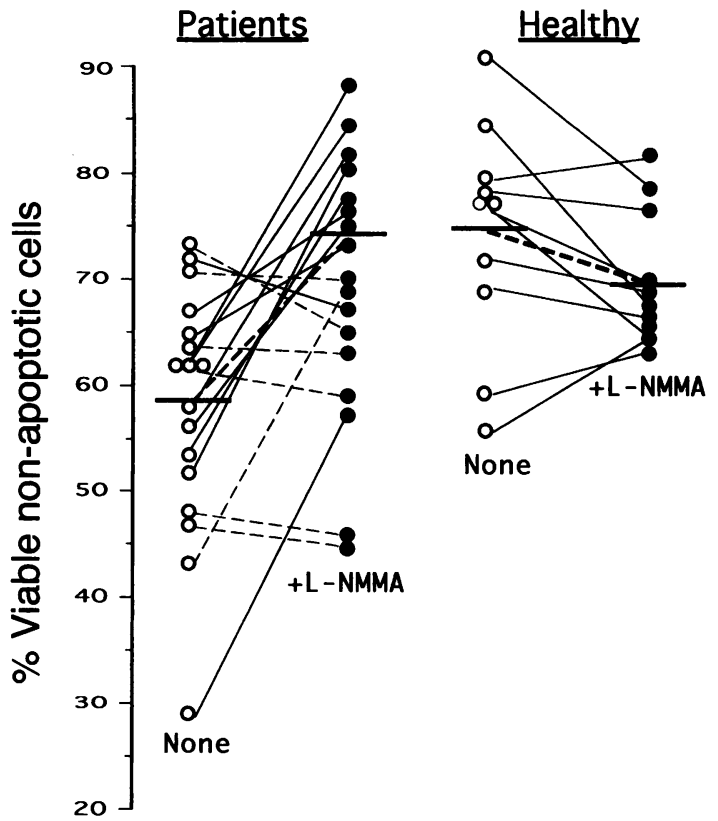

Fig. 2. Effect of NO inhibition on in vitro survival of PBMC. Cells were incubated in medium alone or with $500 \mu \mathrm{M}$ L-NMMA. The percentage of surviving cells was obtained as in Figure 1. For patients with AIDS, continuous lines indicate patients with $<300 \mathrm{CD}^{+}$cells $/ \mathrm{mm}^{3}$ and broken lines, those having $>300 \mathrm{CD}^{+}$cells $/ \mathrm{mm}^{3}$. Thick broken lines show means.

AIDS PBMC with L-NMMA led to a significant increase in cell survival $(p<0.003)$ and rescue from apoptosis in 10/17 patients, whereas others (7/17) showed nonsignificant variations. Cell rescue by L-NMMA, not observed with D-NMMA $(<5 \%$ variability), was greater in patients presenting low peripheral $\mathrm{CD}^{+}$cell counts (Table 3 ) than in patients having higher $\mathrm{CD} 4^{+}$cell counts, except patient $\mathrm{P} 3$. This particular patient presented very

Table 2. Correlation between NO-induced PBMC apoptosis and number of peripheral blood CD4 $^{+}$ cells in patients with AIDS

\begin{tabular}{llcrr}
\hline PBMC from & Untreated & + SNAP & Apoptosis $^{\boldsymbol{b}}(\%)$ & $\boldsymbol{p}^{c}$ \\
\hline AIDS $<300 \mathrm{CD}^{+}$cells $/ \mathrm{mm}^{3}(\times 10)$ & $59 \pm 12$ & $34 \pm 13$ & +43 & $<0.0001$ \\
AIDS $>300 \mathrm{CD}^{+}$cells $/ \mathrm{mm}^{3}(\times 7)$ & $56 \pm 10$ & $41 \pm 13$ & +27 & $<0.005$ \\
Uninfected controls $(\times 10)$ & $75 \pm 8$ & $60 \pm 15$ & +20 & $<0.007$
\end{tabular}

${ }^{a}$ Mean \pm SD of percentage of cell survival following 4-6 days incubation of PBMC in medium alone or with $100 \mu M$ SNAP. ${ }^{b}$ Increased apoptosis in cells incubated with SNAP compared to cells incubated in medium alone.

${ }^{c}$ Significance of SNAP effect on cell survival. 
Table 3. Correlation between L-NMMA-mediated inhibition of PBMC apoptosis and number of $\mathrm{CD4}^{+}$ cells in patients with AIDS

\begin{tabular}{lcccc}
\hline PBMC from & Untreated & +L-NMMA & Apoptosis $^{\boldsymbol{b}}$ (\%) & $\boldsymbol{p}^{c}$ \\
\hline AIDS $<300 \mathrm{CD}^{+}$cells $/ \mathrm{mm}^{3}(\times 10)$ & $59 \pm 12$ & $74 \pm 9$ & -25 & $<0.003$ \\
AIDS $>300 \mathrm{CD}^{+}$cells $/ \mathrm{mm}^{3}(\times 7)$ & $56 \pm 10$ & $61 \pm 11$ & -9 & NS \\
Uninfected controls $(\times 10)$ & $75 \pm 8$ & $70 \pm 12$ & +9 & NS \\
\hline
\end{tabular}

${ }^{a}$ Mean \pm SD of percentage of cell survival following 4-6 days incubation of PBMC in medium alone or with 500 $\mu$ M L-NMMA.

${ }^{b}$ Decreased apoptosis in cells incubated with L-NMMA compared to cells incubated in medium alone.

'Significance of L-NMMA effect on cell survival; NS, not significant.

high levels of HIV-1 RNA copies in his plasma (Table 1). The same experimental approach in three patients with low $\mathrm{CD}^{+}$cell numbers using iNOS-specific inhibitor L-NIL showed an inhibition of apoptosis similar to that observed with L-NMMA $(-20 \%,-24 \%$, and $-38 \%$ apoptosis compared to controls). In addition, L-NMMA and L-NIL treatment clearly decreased the levels of nitrites detected in cell supernatants following these cultures (from $8 \pm 4 \mu \mathrm{M}$ to $2 \pm 2 \mu \mathrm{M}$ ). These data suggest a role for iNOS-mediated endogenous NO generation during the apoptosis of PBMC in AIDS patients having low peripheral $\mathrm{CD}^{+}$cell numbers.

\section{Effects of NO and L-arginine Analog on} Proliferation of PBMC from Patients with AIDS

During HIV-1 infection and AIDS, an impairment of lymphocyte functions occurs, such as unresponsiveness to recall antigens or to stimulation through the CD3/TCR complex, and decreased IL-2 secretion $(1,2)$. We asked whether NO and L-NMMA could affect the growth response of PBMC following $\mathrm{T}$ cell activation. PBMC from 14 patients with AIDS were incubated with plate-bound anti-CD 3 and $I L-2$ in the presence of SNAP $(100 \mu \mathrm{M})$ and/or L-NMMA $(500 \mu \mathrm{M})$, and the number of viable nonapoptotic cells was counted 4 days later. Data in Figure 3 show that the addition of SNAP dramatically decreased cell numbers in most $(9 / 14)$ PBMC cells $(p<0.005)$. Addition of L-NMMA significantly increased $(p<0.03)$ cell responses in most patients with AIDS, regardless of their peripheral $\mathrm{CD}^{+}$cell counts.

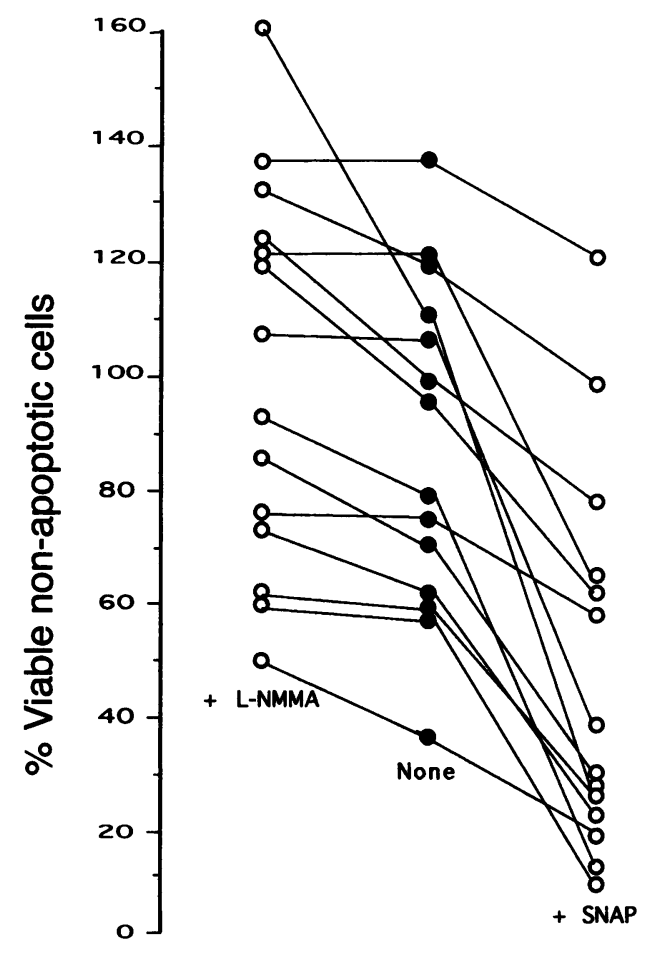

Fig. 3. Effect of NO modulators on PBMC response to $T$ cell activation. Cells were incubated $\left(10^{5} / \mathrm{ml}\right)$ in the presence of anti-CD3-MAb and IL-2, in the absence (black points) or the presence of 500 $\mu M$ L-NMMA (gray circles) or $100 \mu M$ SNAP (white circles). Surviving, nonapoptotic cells were counted as in Figure 1.

No Correlation between Peripheral $\mathrm{CD} 4^{+}$Cell Number and Plasma Levels of Nitrites, TNF- $\alpha$, or HIV-1 Load

In terms of the effects of NO modulation on PBMC, we asked whether circulating NO is increased in $\mathrm{HIV}-\mathrm{I}^{+}$patients. We quantified NO 
levels through plasma concentration of their stable endproduct, nitrites, in plasma from 35 patients with AIDS undergoing HAART (Table 1). Levels of nitrites $(\mu \mathrm{M})$ were then compared with those of plasma TNF- $\alpha(\mathrm{pg} / \mathrm{ml})$, peripheral blood $\mathrm{CD}^{+}$cell counts $\left(\right.$cells $/ \mathrm{mm}^{3}$ ), and viral load (RNA copies/ml) obtained in the same patients. As can be seen in Table 1, we did not find any relationship between these four parameters (plasma nitrites, TNF- $\alpha, \mathrm{CD} 4^{+} / \mathrm{mm}^{3}$, and viral load; $p>0.5$ ). In addition, plasma levels of nitrites were extremely variable $(11.6 \pm 8.4 \mu \mathrm{M})$ and close to those obtained in seronegative controls (9 $\pm 9.6 \mu \mathrm{M}, 41$ donors).

\section{Involvement of Superoxides, PARP, and NAD} Depletion During NO-rrediated Apoptosis of PBMC from Patients with AIDS

Because NO shows significant proapoptotic effects in patient cells, we studied the mechanism of cell death induced by NO in PBMC from three patients with low $\mathrm{CD}^{+}$cell numbers and significant sensitivity to SNAP. As NO induces guanylyl cyclase and subsequent cyclic GMP (cGMP) generation (14), we asked whether cGMP plays a role in cell apoptosis. PBMC were treated with SNAP and specific guanylyl cyclase inhibitors Ly$83,583(30 \mu \mathrm{M})$ or ODQ $(10 \mu \mathrm{m})$. We found no effect on NO-induced apoptosis following cGMP inhibition (data not shown). Because NO may react with superoxide to form peroxynitrites $(15,16)$, we added SOD $(200 \mathrm{U} / \mathrm{ml})$ to cell cultures. As shown in Figure 4, addition of SOD significantly decreased NO-induced apoptosis, which suggests a role for superoxides in this phenomenon. NO is also known to induce cell death via activation of PARP, $\mathrm{NAD}^{+}$depletion, and consequent ATP deficiency (17). This pathway may play a role in NO-mediated neurotoxicity in patients with AIDS (8). Reversion of $\mathrm{NAD}^{+}$deficiency through the addition of exogenous nicotinamide $(5 \mathrm{mM})$ or inhibition of PARP activation by 3 aminobenzamide ( $2 \mathrm{mM}$ ) significantly reversed cell apoptosis mediated by NO (Fig. 4). Rescue from apoptosis was observed in patient cells treated with nicotinamide alone. No inhibition was detected following cell treatment with SNAP or the inactive analogs 3-aminobenzoic acid $(2 \mathrm{mM})$ or nicotinic acid $(5 \mathrm{mM})(23 \pm 8 \%$ and $27 \pm 10 \%$, respectively, compared to $25 \pm$ $9 \%$ with SNAP alone). Together, these experiments suggest the involvement of PARP and $\mathrm{NAD}^{+}$depletion during NO-induced apoptosis.

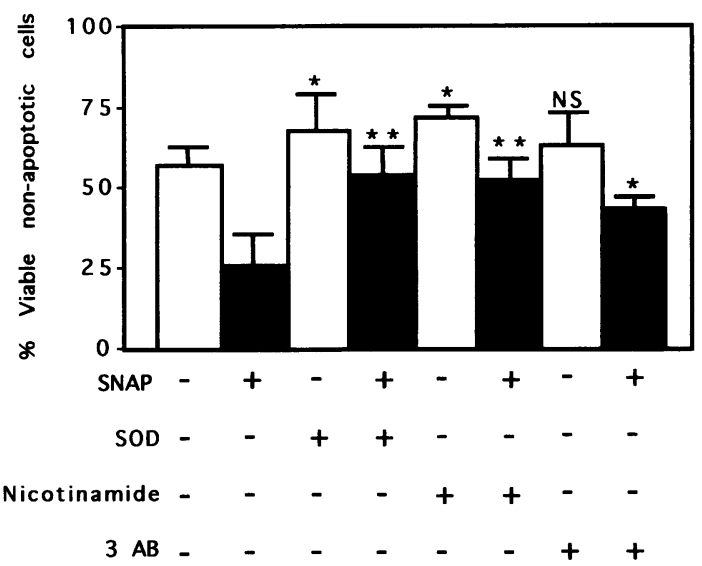

Fig. 4. Mechanism of NO-mediated apoptosis in PBMC from patients with AIDS. Cells were incubated in medium $\left(10^{6} / \mathrm{ml}\right)$ supplemented with SNAP $(100 \mu \mathrm{M})$, SOD $(200 \mathrm{U} / \mathrm{ml})$, nicotinamide (5 $\mathrm{mM})$, and/or 3 aminobenzamide ( $3 \mathrm{AB}, 2 \mathrm{mM}$ ). Percentage of viable, nonapoptotic cells was obtained as in legend to Figure 1 . Mean \pm SD from three different patients. ${ }^{*} p<0.04 ;{ }^{* *} p<0.003$; NS, not significant indicate statistical analysis between cells treated $(+)$ or not (-) with SOD, nicotinamide, or $3 \mathrm{AB}$.

\section{Discussion}

The beneficial effect of HAART is the decrease in HIV load and reversal of HIV-derived activation and $\mathrm{CD}^{+}{ }^{+}$cell defects in patients with AIDS. However, complete leukocyte normalization was not observed in most of these patients (12). The present study shows that PBMC from treated AIDS patients have higher sensitivity to the proapoptotic effect of NO than those from normal controls. This is not surprising, as these cells were shown to be sensitive to other proapoptotic factors, such as FasL, peroxides, or TNF- $\alpha$ (1). Patients with $>300 \mathrm{CD}^{+}$cells $/ \mathrm{mm}^{3}$ showed less sensitivity to NO than those with $<300 \mathrm{CD}^{+}$ cells $/ \mathrm{mm}^{3}$. This indicates that by increasing $\mathrm{CD}^{+}$cell number, HAART can help decrease leukocyte sensitivity to NO-mediated apoptosis.

Our current findings also provide the first evidence that endogenous NO inhibition (by LNMMA or L-NIL) is able to reverse the in vitro apoptosis of patients' cells, a phenomenon that was mainly observed in AIDS patients with decreased in vivo levels of peripheral $\mathrm{CD} 4^{+}$cells. Therefore, endogenous NO may be involved in patient leukocyte susceptibility to undergo apoptosis and may correlate with $\mathrm{CD}^{+}$cell deficiency, despite HAART. Although NO effects on leukocytes remain to be confirmed in vivo, the role of NO derivatives in the neuropathology of 
HIV- 1 infection has been extensively analyzed in vitro and in vivo. Expression of NO and iNOS was observed in situ during HIV-1-associated dementia $(6-8,11,18,19)$. This expression may be due to macrophage activation by HIV-1 gp4l (11) or proinflammatory factors (19-21).

The current study shows the effect of NO on peripheral leukocytes but, as previously reported (22), it fails to establish any correlation between peripheral levels of nitrites or TNF- $\alpha$ and other patient parameters (Table 1). We hypothesize that in vivo expression of NO or TNF- $\alpha$ is likely restricted to specific peripheral tissues rather than having systemic expression. Analysis of iNOS expression in lymph nodes and during disease progression may answer this question.

Higher sensitivity of PBMC from AIDS patients to NO correlates with their decreased levels of reduced glutathione and enhanced oxidized glutathione $(4,23)$. Oxygen derivatives, including NO, may also increase HIV-1 replication through the activation of the $\mathrm{NF} \kappa \mathrm{B}$ transcription factor (24) or induction of TNF- $\alpha$ generation $(21,25)$. Other authors have shown that antioxidants enhance $\mathrm{CD}^{+}{ }^{+}$lymphocyte survival when administered to HIV-1-infected individuals, and inhibit TNF- $\alpha$ - and phorbol myristate acetateinduced cell death in HIV-1-infected cell lines $(3,23)$. This effect was proposed to be mediated through glutathione (GSH) replenishment by $\mathrm{N}$-acetylcysteine treatment. GSH is reported to reverse the proapoptotic effects of NO (3). However, further analysis of NO sensitivity of purified $\mathrm{CD}^{+}$and other leukocyte subpopulations are needed to clarify NO targets.

The mechanism of NO-mediated apoptosis was also investigated. Our preliminary data indicate that NO-induced apoptosis of AIDS patient cells is not mediated through cGMP generation but was significantly reversed following simultaneous addition of SOD, which may suggest the involvement of peroxynitrites in cell death. Inhibition of NO-induced apoptosis by 3-aminobenzamide and nicotinamide point out a role for PARP activation, $\mathrm{NAD}^{+}$depletion, and consequent energy loss during NO-induced apoptosis of PBMC in patients with AIDS. Other authors have reported the involvement of this pathway during NO-mediated neurologic diseases $(8,11)$ as well as the ability of NAD to prevent mitochondria alteration and apoptosis in PBMC from patients with AIDS (26). Altogether, these experiments point out the beneficial effect of iNOS inhibition as an adjuvant therapeutic approach to HAART in order to accelerate $\mathrm{CD}^{+}$cell increase and functional recovery.

\section{Acknowledgments}

We thank Drs. D. Moynet for careful reading of the manuscript, F. Ouaaz and J. L. Boucher for their suggestions, V. Calvez for viral load analysis, and the Internal Medicine Department of Pitié-Salpêtrière Hospital for patient facilities. This work is supported by a grant from the Agence National de Recherches sur le SIDA, ANRS.

\section{References}

1. Fauci AS, Pantaleo G, Stanley S, Weissman D. (1996) Immunopathogenic mechanisms of HIV infection. Ann. Intern. Med. 124: 654-663.

2. Badely AD, Dockrell D, Paya CV. (1997) Apoptosis in AIDS. Adv. Pharmacol. 41: 271-294.

3. Cayota A, Vuillier F, Gonzalez G, Dighiero G. (1996) In vitro antioxidant treatment recovers proliferative responses of anergic $\mathrm{CD} 4^{+}$lymphocytes from human immunodeficiency virus-infected individuals. Blood 87: 4746-4753.

4. Shwarz KB. (1996) Oxidative stress during viral infection: a review. Free Radic. Biol. Med. 21: 641649.

5. Bukrinsky MI, Nottet $H$, Schmidtmayernova $H$, et al. (1995) Regulation of nitric oxide synthase activity in human immunodeficiency virus type 1 (HIV-1)-infected monocytes: implication for HIVassociated neurological disease. J. Exp. Med. 181: 735-745.

6. Adamson DC, McArthur JC, Dawson TM, Dawson VL. (1999) Rate and severity of HIV-associated dementia (HAD): correlations with Gp4l and iNOS. Mol. Med. 5: 98-109.

7. Vincent VA, De Groot CJ, Lucassen PJ, et al. (1999) Nitric oxide synthase expression and apoptotic cell death in brains of AIDS and AIDS dementia patients. AIDS 13: 317-326.

8. Boven LA, Gomes L, Hery C, et al. (1999) Increased peroxynitrite activity in AIDS dementia complex: implications for the neuropathogenesis of HIV-1 infection. J. Immunol. 162: 4319-4327.

9. Weinberg JB. (1998) Nitric oxide production and nitric oxide synthase type 2 expression by human mononuclear phagocytes: a review. Mol. Med. 4: 557-591.

10. Hori K, Burd PR, Furuke K, et al. (1999) Human immunodeficiency virus-1-infected macrophages induce inducible nitric oxide synthase and nitric oxide (NO) production in astrocytes: astrocytic $\mathrm{NO}$ as a possible mediator of neural damage in acquired immunodeficiency syndrome. Blood 93: 1843-1850. 
11. Adamson DC, Wildemann B, Sasaki M, et al. (1996) Immunologic NO synthase: elevation in severe AIDS dementia and induction by HIV-1 gp41. Science 274: 1917-1921.

12. Autran B, Carcelain G, Li TS, et al. (1997) Positive effects of combined antiretroviral therapy on $\mathrm{CD} 4+\mathrm{T}$ cell homeostasis and function in advanced HIV disease. Science 277: 112-116.

13. Becherel PA, Chosidow O, Le Goff L, et al. (1997) Inducible nitric oxide synthase and proinflammatory cytokine expression by human keratinocytes during acute urticaria. Mol. Med. 3: 686-694.

14. Arnold WP, Mittal CK, Katsuki S, Murad F. (1977) Nitric oxide activates guanylate cyclase and increases guanosine $3^{\prime}: 5^{\prime}$-cyclic monophosphate levels in various tissue preparations. Proc. Natl. Acad. Sci. U.S.A. 74: 3203-3207.

15. Darley-Usmar VM, Hogg N, O'Leary VJ, et al. (1992) The simultaneous generation of superoxide and nitric oxide can initiate lipid peroxidation in human low density lipoprotein. Free Radic. Res. Commun. 17: 9-20.

16. Xia Y, Dawson VL, Dawson TM, et al. (1996) Nitric oxide synthase generates superoxide and nitric oxide in arginine-depleted cells leading to peroxynitrite-mediated cellular injury. Proc. Natl. Acad. Sci. U.S.A. 93: 6770-6774.

17. Pieper AA, Verma A, Zhang J, Snyder SH. (1999) Poly (ADP-ribose) polymerase, nitric oxide and cell death. Trends Pharmacol. Sci. 20: 171-181.

18. Gendelman HE, Zheng J, Coulter CL, et al. (1998) Suppression of inflammatory neurotoxins by highly active antiretroviral therapy in human immunodeficiency virus-associated dementia. J. Infect. Dis. 178: 1000-1007.

19. Nuovo GJ, Alfieri ML. (1996) AIDS dementia is associated with massive, activated HIV-1 infection and concomitant expression of several cytokines. Mol. Med. 2: 358-366.

20. Koka P, He K, Zack JA, et al. (1995) Human immunodeficiency virus 1 envelope proteins induce interleukin 1, tumor necrosis factor alpha, and nitric oxide in glial cultures derived from fetal, neonatal, and adult human brain. J. Exp. Med. 182: 941-951.

21. Ouaaz F, Ruscetti FW, Dugas B, et al. (1996) Role of IgE immune complexes in the regulation of HIV-1 replication and increased cell death of infected Ul monocytes: involvement of CD23/FC epsilon RII-mediated nitric oxide and cyclic AMP pathways. Mol. Med. 2: 38-49.

22. Hermann E, Idziorek T, Kusnierz JP, et al. (1997) Role of nitric oxide in the regulation of lymphocyte apoptosis and HIV replication. Int. J. Immunopharmacol. 19: 387-397.

23. Roederer M, Ela SW, Staal FJ, et al. (1992) $N$-acetylcysteine: a new approach to anti-HIV therapy. AIDS Res. Hum. Retroviruses 8: 209-217.

24. Schreck R, Rieber P, Baeuerle PA. (1991) Reactive oxygen intermediates as apparently widely used messengers in the activation of the NF $k B$ transcription factor and HIV. EMBO J. 10: 2247-2258.

25. Bukrinsky $M$, Schmidtmayerova $H$, Zybarth G, et al. (1996) A critical role of nitric oxide in human immunodeficiency virus type 1-induced hyperresponsiveness of cultured monocytes. Mol. Med. 2: 460-468.

26. Savarino A, Martini C, Orofino GC, et al. (1997) Apoptotic DNA fragmentation, and its in vitro prevention by nicotinamide, in lymphocytes from HIV-1-seropositive patients and in HIV-1-infected MT-4 cells. Cell Biochem. Funct. 15: 171-179. 